\title{
PENERAPAN STRATEGI BAURAN PEMASARAN JASA DAN STRATEGI PEMASARAN RELASIONAL TERHADAP PEMBENTUKAN NILAI JASA SERTAINPLIKASINYA PADA KEPERCAYAAN MAHASISWA PERGURUAN TINGGI STUDI PADA SEKOLAH TINGGI SWASTA DI PRIANGAN TIMUR
}

\author{
Oleh : J Sugiat \\ STIE Yasa Anggana Garut \\ Jajangy_anggana@yahoo.co.id
}

\begin{abstract}
Abstrak
Penelitian ini bertujuan untuk mengetahui, menganalisis dan mengkaji Penerapan Strategi Bauran Pemasaran Jasa, Strategi Pemasaran Relasional, Nilai Jasa dan Kepercayaan Mahasiswa serta Pengaruh Penerapan Startegi Bauran Pemasaran Jasa dan Strategi Pemasaran Relasional terhadap Nilai Jasa serta inplikasinya pada Kepercayaan Mahasiswa baik secara simultan dan parsial pada Sekolah Tinggi Swasta di Priangan Timur. Metode yang digunakan dalam penelitian ini menggunakan metode survey penjelasan (Explanatory Survey Method), data dianalisa dengan menggunakan teknik analisis SEM (Structural Equation Modeling) untuk menjelaskan mengenai hubungan dan pengaruh antar variable manifest maupun analisis konfirmatory. Berdasarkan analisis hasil penelitian, diperoleh temuan sebagai berikut, Penerapan Strategi Bauran Pemasaran Jasa ada pada kategori Cukup Baik, Strategi Pemasaran Relasional ada pada kategori Baik, Nilai Jasa ada pada kategori Cukup Baik serta Kepercayaan Mahasiswa ada pada kategori Baik. Strategi Bauran Pemasaran Jasa dan Strategi Pemasaran Relasional berpengaruh secara signifikan terhadap Nilai Jasa serta inplikasinya terhadap Kepercayaan mahasiswa baik secara simultan dan parsial pada Sekolah Tinggi Swasta di Priangan Timur.
\end{abstract}

Kata Kunci: Strategi Bauran Pemasaran Jasa, Strategi Pemasaran Relasional Nilai Jasa dan Kepercayaan Mahasiswa

\section{A. PENDAHULUAN}

Pendidikan merupakan investasi jangka panjang yang harus ditata, disiapkan dengan sarana dan prasarana yang memadai agar mencapai kompetensi, yakni perpaduan pengetahuan, sikap dan keterampilan yang terefleksikan dalam kehidupan sehari-hari. Pendidikan merupakan kewajiban bagi semua warga negara yang harus dilaksanakan untuk meningkatkan kemajuan negara tersebut. Maju dan mundurnya suatu negara ditentukan dari sistem pendidikan yang diterapkan oleh negara itu sendiri. Jika suatu negara ingin maju di bidang industri, maka warga negaranya harus mampu untuk 
menciptakan produk yang berkelas. Jika negara itu ingin maju di bidang teknologi, maka warga negaranya harus dibimbing menjadi seorang pencipta mesin-mesin handal. Begitupun jika ingin meningkat kesejahteraan rakyatnya, maka warga yang dihasilkan haruslah seorang multitalenta sehingga dapat menyesuaikan diri dalam keadaan apapun.

Di Indonesia sendiri segala cara telah dilakukan untuk memajukan pendidikan, baik pendidikan jasmani ataupun rohani di lingkup sekolah maupun di luar sekolah. Namun, banyaknya kendala menghalangi laju perkembangan pendidikan di Indonesia yang masih tergolong rendah. Di era globalisasi pendidikan merupakan hal yang sangat penting untuk memasuki, bertahan dan bersaing di dalamnya. Peningkatan kualitas Sumber Daya Manusia (SDM) perlu diperhatikan agar masyarakat Indonesia mampu bersaing pada zaman ini. Peningkatan Sumber Daya Manusia (SDM) dapat dilakukan melalui penyelenggaraan pendidikan dengan kualitas baik yang mampu memberikan bekal pada generasi penerus untuk dapat sukses di bidang usahanya dengan mampu melewati tingkat persaingan yang semakin tinggi. Seperti yang tertera pada Undang Undang No. 12 Tahun 2012 pasal 4 dan pasal 5 .

Pasal 4 menyebutkan Pendidikan Tinggi berfungsi mengembangkan kemampuan dan membentuk watak serta peradaban bangsa yang bermartabat dalam rangka mencerdaskan kehidupan bangsa, mengembangkan civitas akademika yang inovatif, responshif, kreatif, terampil berdaya saing dan kooperatif melalui pelaksanaan tridharma dan mengembangkan ilmu pengetahuan serta teknologi dengan memperhatikan dan menerapkan nilai humaniora.

Pada pasal 5 menyebutkan Pendidikan Tinggi bertujuan untuk mengembangkan potensi mahasiswa agar menjadi manusia yang beriman dan bertakwa kepada Tuhan Yang Maha Esa, berakhlak mulia, sehat, berilmu, cakap, kreatif, mandiri, terampil, kompeten dan berbudaya untuk kepentingan bangsa. Dihasilkannya lulusan yang menguasai cabang ilmu pengetahuan dan atau teknologi untuk memenuhi kepentingan nasional dan meningkatkan daya saing bangsa. Dihasilkan ilmu pengetahuan dan teknologi melalui penelitian yang memperhatikan nilai humaniora agar bermanfaat bagi kemajuan bangsa, serta kemajuan peradaban dan kesejahteraan umat manusia. Serta terwujudnya pengabdian pada masyarakat berbasis penalaran dan karya penelitian yang bermanfaat dalam memajukan kesejahteraan umum dan mencerdaskan kehidupan bangsa.

\section{Berdasarkan Undang Undang dan} Peraturan Pemerintah yang sudah dikemukakan, maka dapat diketahui bahwa pendidikan memiliki peranan yang sangat penting dalam menentukan perkembangan dan perwujudan diri individu, terutama bagi pembangunan bangsa dan negara. Kemajuan suatu kebudayaan tergantung pada cara kebudayaan tersebut mengenali, menghargai, dan memanfaatkan sumber daya manusia yang dalam hal ini berkaitan erat dengan kualitas pendidikan yang 
diberikan kepada anggota masyarakat sebagai peserta didik.

$$
\text { Belum meratanya tingkat }
$$
pendidikan di Indonesia dikarenakan berbagai faktor, seperti hambatan secara geografis dimana lokasi rumah yang jauh dari kampus, diskriminasi gender yang lebih mendahulukan anak laki laki untuk mengenyam pendidikan yang lebih tinggi dari anak perempuannya. Hambatanpun muncul dari sisi perekonomian yaitu kemiskinan yang berhubungan dengan daya beli masyarakat sekitar untuk dapat mengenyam bangku pendidikan yang saat ini semakin mahal, sehingga hanya orang yang mampu secara ekonomi sajalah yang bisa menikmati dunia pendidikan khususnya di Perguruan Tinggi (PT). Keadaan ini sangat bertentangan dengan pembukaan UUD 1945 alinea ke-4 yang berisi pendidikan nasional bertujuan mencerdaskan kehidupan bangsa. Juga pada pasal 28 B ayat (1) dikatakan bahwa setiap orang berhak mengembangkan pemenuhan kebutuhan dasarnya, berhak mendapat pendidikan dan mendapatkan manfaat dari ilmu pengetahuan dan teknologi, seni dan budaya, demi meningkatkan kualitas hidupnya, demi kesejahteraan umat manusia. Keadaan ini juga bertentangan dengan pasal 31 ayat (1) yang berisi bahwa setiap warga negara berhak mendapatkan pendidikan.

Pendidikan menjadi hak setiap Warga Negara Indonesia. Pendidikan merupakan fondasi yang sangat penting guna membawa bangsa dan negara ini kepada kemajuan. Pendidikan dibutuhkan untuk menjawab kebutuhan pasar akan tenaga kerja berkualitas yang mampu bersaing di era globalisasi. Karena, tidak dipungkiri gelar Strata-1 (S1) menjadi syarat minimum untuk dapat bersaing di era-globalisasi seperti sekarang ini.

\section{Sumber Daya Manusia (SDM)} lulusan dari perguruan tinggi bukan menjadi sebuah jaminan bahwa SDM tersebut berkualitas, hal ini ditunjukan dengan masih banyaknya sarjana yang menganggur karena tidak terserap pada lapangan pekerjaan yang ada, baik di perusahaan nasional maupun perusahaan asing. Hal tersebut sejalan dengan data yang diterbitkan oleh Badan Pusat Statistik (BPS) bahwa tingkat pengangguran di Provinsi Jawa Barat mengalami peningkatan pada tahun 2016 bertambah 23.783 sehingga berjumlah 1.899 .707 orang dibanding tahun 2015 sejumlah 1.875.929. Sehingga Jawa Barat menempati posisi ke-3 secara Nasional Provinsi yang memiliki angka pengangguran yang tinggi. Keadaan inilah yang menjadi salah satu penyebab terbentuknya paradigma baru dalam masyarakat bahwa mahasiswa yang masuk perguruan tinggi masih dipertanyakan kualitas dan kompetensinya.

Dengan berbagai keluhan
masyarakat akan rendahnya kualitas penyelenggaraan Perguruan Tinggi seperti dengan maraknya penerbitan Ijazah palsu, penyelenggaraan kelas jauh dan kegiatan perkuliahan dengan pemadatan, membentuk persepsi yang negatif akan kualitas pelayanan perguruan Tinggi di Indonesia, Sehingga menurunkan kepercayaan masyarakat dan pengguna lulusan dalam hal ini perusahaan terhadap kualitas 
penyelenggaraan Perguruan Tinggi dalam memenuhi kebutuhan dan tuntutan perkembangan jaman sekarang ini.

Sebagai upaya untuk menyesuaikan tuntutan globalisasi khususnya di bidang pendidikan, pemerintah bekerjasama dengan masyarakat berkomitmen untuk dapat menyelenggarakan kegiatan pendidikan yang berkualitas. Ditunjukan dengan semakin banyaknya perguruan tinggi di daerah yang diselenggarakan baik oleh Perguruan Tinggi Negeri (PTN) maupun Perguruan Tinggi Swasta (PTS), dengan biaya pendidikan yang lebih terjangkau dibandingkan dengan kuliah di kota besar.

\section{Buchari dan Ratih (2009:38),} menyatakan bahwa mahasiswa yang masuk ke sebuah perguruan tinggi tentu mempunyai banyak harapan dengan adanya kematangan kepribadian, pengalaman berinteraksi di kampus, kesempatan lapangan kerja, pengembangan karir dan adanya rasa bangga sebagai mahasiswa perguruan tinggi tersebut. Untuk menjadi sekolah tinggi yang unggul, maka setiap Sekolah Tinggi wajib menerapkan sistem manajemen yang tepat, sehingga organisasi dapat dengan tepat pula mengalokasikan sumber daya yang diperlukan untuk mencapai tujuan organisasi yaitu memberikan jasa terbaik kepada masyarakat di bidang pendidikan.

Sampai dengan tahun 2016, perkembangan jumlah mahasiswa Sekolah Tinggi Swasta di Priangan Timur mengalami penurunan. Hal ini terjadi pada sebagian besar Sekolah Tinggi Swasta dimana jumlah mahasiswa terus mengalami penurunan setiap tahun. Hanya beberapa Sekolah Tinggi Swasta yang mampu mempertahankan jumlah mahasiswanya bahkan bisa menaikkan angka dari tahun sebelumnya. Peningkatan maupun penurunan jumlah mahasiswa setiap tahun dapat menjadi salah satu dasar untuk melihat tingkat kepercayaan mahasiswa di Sekolah Tinggi Swasta bersangkutan. Kepercayaan merupakan kesediaan seseorang untuk bertumpu dan memiliki perasaan yakin yang kemudian diberikan pada orang lain dalam situasi tertentu. Kepercayaan terjadi ketika seseorang yakin dengan reliabilitas dan integritas dari pihak yang dipercaya. Keyakinan terhadap pihak yang memiliki reliabilitas dan integritas akan memberikan nilai kepercayaan terhadap pihak tersebut sehingga seseorang dapat memberikan kayakinan terhadap sesuatu, yaitu jasa pendidikan dari Sekolah Tinggi Swasta.

Berdasarkan hasil pra penelitian kepada 30 responden Sekolah Tinggi Swasta di Priangan Timur, menunjukkan bahwa Nilai Jasa terhadap Sekolah Tinggi Swasta di Priangan Timur belum terbentuk optimal. Adapun hasil pra penelitian terkait dengan Nilai Jasa Sekolah Tinggi Swasta di Priangan Timur dapat dilihat pada gambar 1.7 di bawah ini: 
Tabel 1

Nilai Jasa Sekolah Tinggi Swasta di Priangan Timur

\begin{tabular}{|c|c|c|c|c|c|c|c|c|}
\hline \multirow[t]{2}{*}{ No } & \multirow[t]{2}{*}{ Dimensi } & \multirow[t]{2}{*}{ Pernyataan } & SB & B & CB & KB & TB & $\begin{array}{c}\text { Tota } \\
1\end{array}$ \\
\hline & & & 5 & 4 & 3 & 2 & 1 & \\
\hline 1 & $\begin{array}{l}\text { Nilai } \\
\text { Produk }\end{array}$ & $\begin{array}{ll}\text { Peringkat } & \text { Akreditasi } \\
\text { sudah baik } & \end{array}$ & 0 & 11 & 18 & 1 & 0 & 30 \\
\hline 2 & $\begin{array}{l}\text { Nilai } \\
\text { Pelayanan }\end{array}$ & $\begin{array}{l}\text { Pelayanan akademik yang } \\
\text { diberikan sudah baik }\end{array}$ & 0 & 7 & 15 & 8 & 0 & 30 \\
\hline 3 & $\begin{array}{l}\text { Nilai } \\
\text { Karyawan }\end{array}$ & $\begin{array}{lr}\text { Karyawan } & \text { lembaga } \\
\text { memiliki } & \text { kompetensi } \\
\text { yang baik } & \end{array}$ & 0 & 6 & 15 & 9 & 0 & 30 \\
\hline 4 & $\begin{array}{l}\text { Nilai } \\
\text { Citra }\end{array}$ & $\begin{array}{l}\text { Sekolah tinggi memiliki } \\
\text { budaya organisasi yang } \\
\text { baik }\end{array}$ & 0 & 10 & 14 & 6 & 0 & 30 \\
\hline & uensi & & $\mathbf{0}$ & 34 & 62 & 24 & $\mathbf{0}$ & 120 \\
\hline Sko & & & $\mathbf{0}$ & 136 & 186 & 48 & $\mathbf{0}$ & 370 \\
\hline & entase (\%) & & 0,0 & 36,7 & 50,2 & 12,9 & $\mathbf{0 , 0}$ & 100 \\
\hline Rat & -rata & & & & & & & \\
\hline
\end{tabular}

Ket: $\mathrm{SB}=$ Sangat Baik, B= Baik, CB = Cukup Baik, KB = Kurang Baik, TB = Tidak Baik,

Sumber : Data diolah dari kuesioner

Berdasarkan Tabel 1, mengenai nilai jasa pada Sekolah Tinggi Swasta di Priangan Timur, menunjukkan pada kriteria "Cukup Baik" dengan rata-rata 3,08, hal ini sesuai dengan penafsiran Sugiyono (2012), berarti nilai jasa belum didukung oleh organisasi melalui berbagai dimensi yang menyertainya, sehingga perlu mendapatkan perhatian dalam meningkatkan kepercayaan mahasiswa terutama pada indikator nilai karyawan, yaitu karyawan lembaga memiliki kompetensi yang baik. Hal ini menggambarkan para mahasiswa masih menilai jika karyawan lembaga belum memiliki kepekaan, kompetensi, maupun sikap yang ramah dalam memberikan pelayanan terhadap mahasiswa sehingga mahasiswa masih mendapatkan kesulitan, informasi yang kurang jelas maupun rasa 
nyaman yang diperolehnya dari pihak karyawan.

Kotler \& Keller (2006:25) mengungkapkan pula bahwa: "Suatu perusahaan berhasil menawarkan produk/jasa kepada pelanggan apabila mampu memberikan nilai dan kepuasan (value and satisfaction)." Nilai (value) adalah perkiraan konsumen atas seluruh kemampuan produk untuk memuaskan kebutuhannya."

Sedangkan menurut Barnes (2001:104) mengungkapkan bahwa, "Nilai bersifat pribadi dan unik." Nilai dikatakan bersifat pribadi dan unik karena nilai terkait dengan manfaat yang mereka terima dari sebuah produk dan biaya yang harus dikeluarkan untuk dapat merasakan manfaat tersebut.

Dari data di atas terlihat bahwa tanggapan mahasiswa masih rendah terhadap strategi bauran pemasaran jasa yang di tawarkan sekolah tinggi swasta di Priangan Timur terutama yang berhubungan dengan keberagaman program studi yang ditawarkan, peringkat akreditasi yang masih rata rata peringkat $\mathrm{B}$. Kebanggaan terdaftar sebagai mahasiswa pada perguruan tinggi, dan kualitas lulusan yang mudah terserap lapangan pekerjaan persepsinya masih rendah.

Strategi bauran pemasaran jasa menjadi faktor penting dalam meningkatkan nilai jasa dan loyalitas yang berpengaruh terhadap kepercayaan mahasiswa. Menurut Lodh (2017) menyarankan perusahaan harus merancang strategi yang baik untuk di gunakan sebagai usaha mendorong dan menciptakan perasaan puas pelanggannya sehingga dapat menciptakan pelanggan yang loyal. Kepuasan yang dirasakan oleh konsumen dicapai melalui perancangan strategi pemasaran yang baik dan tepat. Sedangkan menurut Revald dan Gronrooss (1996) mengemukakan bahwa pendorong utama peningkatan nilai jasa adalah peningkatan kinerja bauran pemasaran jasa (dengan dukungan pengaruh factor internal dan faktor eksternal individu).

Lebih lanjut menurut Kotler dan Amstrong dalam Tjiptono (2008;160) Apabila Pelanggan merasa puas terhadap Bauran Pemasaran Jasa, maka pelanggan akan melakukan pemakaian jasa ulang, bahkan lebih jauh lagi, mereka akan melakukan promosi dari mulut ke mulut kepada rekan, saudara atau kenalan terdekatnya agar sama sama menggunakan pelayanan jasa untuk berbagai keperluan diperusahaan yang sama.

Berdasarkan hasil pra penelitian kepada 30 responden Sekolah Tinggi Swasta di Priangan Timur, menunjukkan bahwa strategi bauran pemasaran jasa terhadap Sekolah Tinggi Swasta di Priangan Timur kurang optimal. Adapun hasil pra penelitian terkait dengan strategi bauran pemasaran jasa Sekolah Tinggi Swasta di Priangan Timur dapat dilihat pada tabel 2 di bawah ini: 
Tabel 2

Strategi Bauran Pemasaran Jasa

Sekolah Tinggi Swasta di Priangan Timur

\begin{tabular}{|c|c|c|c|c|c|c|c|c|}
\hline \multirow[t]{2}{*}{ No } & \multirow[t]{2}{*}{$\begin{array}{l}\text { Dimens } \\
\quad \text { i }\end{array}$} & \multirow[t]{2}{*}{ Pernyataan } & SB & B & $\mathbf{C B}$ & KB & TB & $\begin{array}{c}\text { Tota } \\
1\end{array}$ \\
\hline & & & 5 & 4 & 3 & 2 & 1 & \\
\hline 1 & Produk & $\begin{array}{lr}\text { Program Studi yang } \\
\text { ditawarkan } & \text { sesuai } \\
\text { dengan kebutuhan } & \end{array}$ & 2 & 10 & 15 & 3 & 0 & 30 \\
\hline 2 & Harga & $\begin{array}{l}\text { Besarnya biaya } \\
\text { pendidikan terjangkau }\end{array}$ & 3 & 9 & 12 & 6 & 0 & 30 \\
\hline 3 & Promosi & Promosi yang dilakukan & 3 & 10 & 14 & 3 & 0 & 30 \\
\hline 4 & Tempat & $\begin{array}{ll}\text { Lokasi } & \text { mudah } \\
\text { dijangkau } & \end{array}$ & 4 & 14 & 9 & 3 & 0 & 30 \\
\hline 5 & Orang & $\begin{array}{l}\text { Kredibilitas dosen yang } \\
\text { dimiliki }\end{array}$ & 2 & 10 & 14 & 4 & 0 & 30 \\
\hline 6 & Proses & Kecepatan pelayanan & 2 & 8 & 12 & 8 & 0 & 30 \\
\hline 7 & Sarana & $\begin{array}{l}\text { Gedung dan sarana } \\
\text { pembelajaran }\end{array}$ & 4 & 8 & 13 & 5 & 0 & 30 \\
\hline \multicolumn{3}{|c|}{ Frekuensi } & 20 & 69 & 89 & 32 & $\mathbf{0}$ & 210 \\
\hline \multicolumn{3}{|c|}{ Skor } & 100 & 276 & 267 & 64 & $\mathbf{0}$ & 707 \\
\hline \multicolumn{3}{|c|}{ Persentase (\%) } & 14,1 & 39,0 & 37,7 & 9,0 & $\mathbf{0 , 0}$ & 100 \\
\hline \multicolumn{3}{|c|}{ Rata-rata } & \multicolumn{6}{|c|}{3,37} \\
\hline
\end{tabular}

Ket: $\mathrm{SB}=$ Sangat Baik, $\mathrm{B}=$ Baik, $\mathrm{CB}=$ Cukup Baik, $\mathrm{KB}=$ Kurang Baik, $\mathrm{TB}=$ Tidak Baik,

\section{Sumber : Data diolah dari kuesioner}

Berdasarkan Tabel 2, mengenai strategi bauran pemasaran jasa pada Sekolah Tinggi Swasta di Priangan Timur, menunjukkan pada kriteria "Cukup Baik" dengan rata-rata 3,37, hal ini sesuai dengan penafsiran Sugiyono (2012). Berarti bauran pemasaran jasa belum didukung oleh

tanggung jawab atas keberlangsungan organisasi, sehingga perlu mendapatkan perhatian dalam meningkatkan nilai jasa terutama pada indikator kecepatan pelayanan yang menunjukkan kepercayaan mahasiswa untuk memilih Sekolah Tinggi Swasta masih rendah. 
Dari data di atas terlihat bahwa tanggapan mahasiswa masih rendah terhadap strategi bauran pemasaran jasa yang di tawarkan sekolah tinggi swasta di Priangan Timur terutama yang berhubungan dengan keberagaman program studi yang ditawarkan, peringkat akreditasi yang masih rata rata predikat B. Kebanggaan terdaftar sebagai mahasiswa pada perguruan tinggi, dan kualitas lulusan yang mudah terserap lapangan pekerjaan persepsinya masih rendah.

Lebih lanjut menurut Kotler dan Amstrong dalam Tjiptono $(2008 ; 160) \quad$ Apabila Pelanggan merasa puas terhadap Bauran Pemasaran Jasa, maka pelanggan akan melakukan pemakaian jasa ulang, bahkan lebih jauh lagi, mereka akan melakukan promosi dari mulut ke mulut kepada rekan, saudara atau kenalan terdekatnya agar sama sama menggunakan pelayanan jasa untuk berbagai keperluan diperusahaan yang sama.
Menurut Christopher, Payne dan Ballantyne (2000:32). Perusahaan perlu melakukan pendekatan relationship marketing yang terbaik untuk membangun hubungan jangka panjang dengan pelanggan, dan kemudian menarik pelanggan yang baru. Proses ini membangun dan menciptakan nilai-nilai baru dengan pelanggan individu, dan berbagi manfaat seumur hidup dengan mereka itu sangat penting bagi perusahaan karena relationship marketing menciptakan loyalitas pelanggan dan keuntungan jangka panjang bagi perusahaan.

Berdasarkan hasil pra penelitian kepada 30 responden Sekolah Tinggi Swasta di Priangan Timur, menunjukkan bahwa strategi pemasaran relasional terhadap Sekolah Tinggi Swasta di Priangan Timur kurang optimal. Adapun hasil pra penelitian terkait dengan relation marketing Sekolah Tinggi Swasta di Priangan Timur dapat dilihat pada gambar 1.9 di bawah ini:

Tabel 3

\section{Strategi Pemasaran Relasional}

\section{Sekolah Tinggi Swasta Priangan Timur}

\begin{tabular}{|c|l|l|c|c|c|c|c|c|}
\hline No & \multirow{2}{*}{ Dimensi } & \multicolumn{1}{|c|}{ Pernyataan } & SB & B & CB & KB & TB & $\begin{array}{c}\text { Tota } \\
\text { I }\end{array}$ \\
\cline { 3 - 9 } & $\begin{array}{l}\text { Kepercayaa } \\
\text { n (Trust) }\end{array}$ & $\begin{array}{l}\text { Lembaga selalu } \\
\text { berusaha jujur dan } \\
\text { dapat dipercaya }\end{array}$ & 2 & 10 & 15 & 3 & 0 & 30 \\
\hline 2 & $\begin{array}{l}\text { Ketergantun } \\
\text { gan }\end{array}$ & $\begin{array}{l}\text { Staf lembaga } \\
\text { kompeten dalam }\end{array}$ & 2 & 8 & 15 & 5 & 0 & 30 \\
\hline
\end{tabular}




\begin{tabular}{|c|c|c|c|c|c|c|c|c|}
\hline \multirow[t]{2}{*}{ No } & \multirow[t]{2}{*}{ Dimensi } & \multirow[t]{2}{*}{ Pernyataan } & SB & B & CB & $\mathbf{K B}$ & TB & $\begin{array}{c}\text { Tota } \\
1\end{array}$ \\
\hline & & & 5 & 4 & 3 & 2 & 1 & \\
\hline & (Bonding) & $\begin{array}{l}\text { memberikan } \\
\text { pelayanan }\end{array}$ & & & & & & \\
\hline 3 & $\begin{array}{l}\text { Empati } \\
\text { (Empathy) }\end{array}$ & $\begin{array}{l}\text { Pihak lembaga } \\
\text { memberikan perhatian } \\
\text { yang baik terhadap } \\
\text { mahasiswa }\end{array}$ & 3 & 11 & 9 & 7 & 0 & 30 \\
\hline 4 & $\begin{array}{l}\text { Timbal balik } \\
\text { (Reciprocity }\end{array}$ & $\begin{array}{l}\text { Reputasi lembaga } \\
\text { dibangun dengan baik }\end{array}$ & 4 & 10 & 11 & 5 & 0 & 30 \\
\hline \multicolumn{3}{|c|}{ Frekuensi } & 11 & 39 & 50 & 20 & $\mathbf{0}$ & 120 \\
\hline \multicolumn{3}{|c|}{ Skor } & 55 & 156 & 150 & 40 & $\mathbf{0}$ & 401 \\
\hline \multicolumn{3}{|c|}{ Persentase (\%) } & 13,7 & 38,9 & 37,4 & 9,9 & $\mathbf{0 , 0}$ & 100 \\
\hline \multicolumn{3}{|c|}{ Rata-rata } & \multicolumn{6}{|c|}{3,34} \\
\hline
\end{tabular}

Ket: $\mathrm{SB}=$ Sangat Baik, B= Baik, CB = Cukup Baik, $\mathrm{KB}=$ Kurang Baik, TB = Tidak Baik,

\section{Sumber : Data diolah dari kuesioner}

Berdasarkan Tabel 3, mengenai strategi pemasaran relasional pada Sekolah Tinggi Swasta di Priangan Timur, menunjukkan pada kriteria "Cukup Baik" dengan rata-rata 3,34, hal ini sesuai dengan penafsiran Sugiyono (2012). Selain strategi bauran pemasaran jasa, strategi relation marketing menjadi faktor penting dalam meningkatkan nijai jasa dan loyalitas yang berpengaruh terhadap kepercayaan mahasiswa. Strategi pemasaran relasional (relationship marketing) adalah konsep yang sangat penting untuk menarik dan mempertahankan pelanggan dalam sebuah organisasi, relationship marketing membangun, memelihara dan selalu meningkatkan hubungan yang baik dengan pelanggan merupakan aspek penting dari bisnis jasa yang dapat dilaksanakan dalam sebuah sekolah tinggi. Konsep pemasaran relasional (relationship marketing) secara luas dipahami, baik itu secara akademis dan profesional dimana tujuannya adalah untuk meningkatkan hubungan yang kuat dan menjadikan pelanggan loyal.

Menurut Christopher, Payne dan Ballantyne (2000:32). Perusahaan perlu melakukan pendekatan relationship marketing yang terbaik untuk membangun hubungan jangka panjang dengan pelanggan, dan kemudian menarik 
pelanggan yang baru. Proses ini membangun dan menciptakan nilai-nilai baru dengan pelanggan individu, dan berbagi manfaat seumur hidup dengan mereka itu sangat penting bagi perusahaan karena relationship marketing menciptakan loyalitas pelanggan dan keuntungan jangka panjang bagi perusahaan.

Berdasarkan pada fenomena tersebut di atas, maka peneliti tertarik melakukan penelitian tentang: PENERAPAN STRATEGI BAURAN PEMASARAN JASA DAN STRATEGI PEMASARAN RELASIONAL TERHADAP PEMBENTUKAN NILAI JASA PERGURUAN TINGGI STUDI PADA SEKOLAH TINGGI SWASTA DI PRIANGAN TIMUR

\section{B. Metode Penelitian}

Metodologi penelitian menguraikan langkah-langkah yang perlu dilakukan oleh peneliti yang mencakup tahapan: persiapan, pengumpulan data dan informasi, pengolahan data, kajian dan analisis untuk mendapatkan gambaran secara menyeluruh dan sistematis mengenai penelitian. Penelitian ini dibatasi pada kajian ilmu manajemen dengan fokus disiplin ilmu manajemen pemasaran. Riset pemasaran (Malhotra alih bahasa Soleh R. M, 2009:7) adalah "Fungsi yang menghubungkan konsumen, pelanggan, dan masyarakat dengan pemasar melalui informasiinformasi yang digunakan untuk mengidentifikasikan dan mendefinisikan peluang dan masalah pemasaran, membuat, memperbaiki dan mengevaluasi tindakan pemasaran, memantau kinerja pemasaran, serta memperbaiki pengertian mengenai pemasaran sebagai sebuah proses".

Penelitian ini bertujuan untuk mendapatkan gambaran, menganalisis dan mengkaji tentang strategi bauran pemasaran jasa dan nilai jasa Sekolah Tinggi Swasta di Priangan Timur. Metode penelitian yang digunakan, metode deskriptif dan verifikatif, dengan penekanan pada eksplorasi dan interpretasi hasil penelitian, yang mempunyai tujuan untuk menganalis ada tidaknya saling hubungan antara variabel Strategi Bauran Pemasaran Jasa dan Nilai Jasa. Oleh karena itu, dalam pelaksanaan penelitian ini digunakan dua metode penelitian, yakni deskriptif dan verifikatif.

Dengan demikian, metode deskriptif digunakan untuk menjawab tujuan penelitian, yaitu untuk mengetahui Strategi Bauran Pemasaran Jasa, Strategi Pemasaran Relasional dan Nilai jasa pada Sekolah Tinggi Swasta di Priangan Timur. Sementara metode verifikatif digunakan untuk menjawab tujuan penelitian: Besarnya pengaruh Strategi Bauran Pemasaran Jasa dan Strategi Pemasaran Relasional terhadap Nilai Jasa pada Sekolah Tinggi Swasta di Priangan Timur.

Dalam penelitaian ini, metode yang digunakan adalah metode explanatory survey dengan jenis penelitian verifikatif. Dalam melakukan studi korelasional digunakan metode explanatory yang bertujuan untuk menjelaskan alasan-alasan dari suatu fenomena yang hanya diobservasi oleh studi deskriptif (Cooper dan Schindler, 2006;21). Sesuai dengan 
tujuannya, penelitian ini untuk menjelaskan hubungan kausalitas antara konsep-konsep penelitian dan pengujian hipotesis guna mengambil keputusan secara induktif atau generalisasi, maka penelitian ini bersifat penjelasan (explanatory research). Sedangkan, metode survei digunakan untuk mendapatkan data dari tempat tertentu yang alamiah (bukan buatan), tetapi peneliti melakukan perlakuan dalam pengumpulan data, misalnya dengan mengedarkan kuisioner, test, wawancara terstruktur dan sebagainya (Sugiyono, 2012:6).

\section{Hasil Dan Pembahasan}

\subsection{Strategi Bauran Pemasaran Jasa}

Berdasarkan hasil analisis dari setiap item pertanyaan strategi bauran pemasaran jasa diukur dalam tujuh dimensi yaitu: product (produk), price (harga), place (tempat), promotion (promosi), people (SDM), pysical evidence (sarana dan prasarana), dan process (proses). Adapun nilai- rata-rata variabel strategi bauran pemasaran jasa $\left(\mathrm{X}_{1}\right)$ sebesar 3,37 dengan standar deviasi 0,49590, dengan demikian kriteria strategi bauran pemasaran jasa ada pada kategori cukup baik sampai dengan baik. Kondisi strategi bauran pemasaran dapat terlihat dari:

Dimensi product (produk) dalam katagori baik dengan rata-rata 3,59, menunjukkan bahwa kualitas dan variasi Program Studi pada Sekolah Tinggi Swasta di Priangan Timur sudah dianggap baik termasuk predikat Akreditasi Program Studi dan Akreditasi Institusi Perguruan Tinggi sehingga meningkatkan nilai jasa dan loyalitas mahasiswa terhadap lembaganya.
Dimensi price (harga) dalam katagori baik dengan rata-rata sebesar 3,49, artinya Sekolah Tinggi Swasta di Pringan Timur menetapkan biaya pendaftaran, biaya pendidikan dan kesesuaian besaran biaya yang di tetapkan dengan kualitas pelayanan sudah dianggap terjangkau oleh mahasiswa dan masyarakat sehingga dapat bersaing dengan lembaga lain tetapi perlu diimbangi dengan layanan yang berkualitas, dan harga perlu ditetapkan dengan jelas, sehingga mahasiswa akan mengetahui dan percaya terhadap Sekolah Tinggi Swasta yang dipilihnya.

Dimensi promotion (promosi) dalam katagori cukup baik dengan rata-rata sebesar 3,33, dalam hal ini promosi Sekolah Tinggi Swasta Priangan Timur perlu ditingkatkan misalnya: adanya iklan sebagai bagian dari promosi Sekolah Tinggi Swasta, agar pesan tersampaikan kepada masyarakat sebagai calon mahasiswa, sehingga minat untuk masuk ke Sekolah Tinggi Swasta di Priangan Timur bisa lebih meningkat.

Dimensi place (tempat) dalam katagori cukup baik dengan rata-rata sebesar 3,29, artinya bahwa Sekolah Tinggi Swasta yang berada di wilayah Priangan Timur perlu mempertimbangkan letak kampus yang strategis, mengutamakan akses transportasi umum menuju lokasi kampus, sehingga mempermudah mahasiswa untuk melakukan kegiatan dan aktivitas perkuliahan.

Dimensi people (orang) dalam katagori cukup baik dengan rata-rata sebesar 2,97, dalam hal ini Sekolah Tinggi Swasta di Priangan Timur harus tetap memperhatikan kualitas tenaga pendidik 
dosen dan tenaga kependidikan/staf yang merupakan bagian yang tidak terpisahkan dari kualitas layanan lembaga pendidikan tinggi termasuk pada Sekolah Tinggi Swasta di Priangan Timur.

Dimensi process (proses) dalam katagori cukup baik dengan rata-rata sebesar 3,25, dalam hal ini Sekolah Tinggi Swasta di Priangan Timur harus memberikan pelayanan yang baik dan berkualitas, sehingga mahasiwa tidak memperoleh kesulitan jika konsultasi atau bertanya tentang hal yang menyangkut perkuliahan.

Dimensi physical evidence (sarana dan prasarana) dalam katagori baik dengan rata-rata sebesar 3,70, dalam hal ini sarana dan prasarana pembelajaran yang tersedia pada Sekolah Tinggi Swasta di Priangan Timur harus dapat mendukung bakat minat mahasiswa yang tersedia pada Perguruan Tinggi yang bersangkutan.

Dimensi physical evidence (sarana dan prasarana), product (produk), price (harga), adalah dimensi yang terbesar, sedangkan dimensi place (tempat) dan promotion (promosi) dan process (proses) dimensi terbesar kedua, dimensi yang paling terendah people (orang). Untuk dimensi yang tertinggi perlu dipertahankan dan ditingkatkan lagi, sedangkan untuk dimensi-dimensi yang terendah perlu dilakukan perbaikan, apabila ke tujuh dimensi ini diterapkan secara berkesinambungan maka akan berpengaruh terhadap Nilai jasa dan Loyalitas mahasiswa yang pada akhirnya akan meningkatkan kepercayaan mahasiswa.

\subsection{Strategi Pemasaran Relasional}

Berdasarkan hasil analisis dari setiap item pertanyaan strategi pemasaran relasional diukur dalam empat dimensi yaitu: trust (kepercayaan), bonding (ketergantungan/ikatan), empaty (empati), reciprocity (timbal balik). Adapun nilairata-rata variabel strategi relasi pemasaran $\left(\mathrm{X}_{2}\right)$ sebesar 3,48 dengan standar deviasi 0,45681 , dengan demikian kriteria strategi relasi pemasaran cukup baik sampai dengan baik. Kondisi strategi relasi pemasaran dapat terlihat dari:

Dimensi trust (kepercayaan), dalam katagori cukup baik dengan rata-rata 3,39, dalam hal ini pihak Sekolah Tinggi Swasta perlu menunjukan kejujuran Perguruan Tinggi dalam menyelenggarakan pendidikan bagi mahasiswa dan masyarakat dan keseriusan Perguruan Tinggi dalam meningkatkan kualitas pelayanan pendidikannya.

\section{Dimensi}

bonding (ketergantungan/ikatan), dalam katagori baik dengan rata-rata 3,46 hal ini pihak Sekolah Tinggi Swasta di Priangan Timur harus berupaya dalam menjaga lingkungan kampus yang bersih untuk menciptakan kenyamanan dalam belajar.

Dimensi empaty (empati), dalam katagori baik dengan rata-rata 3,69, pihak Sekolah Tinggi Swasta di Priangan Timur harus menunjukkan Kepedulian Lembaga terhadap Permasalahan yang dihadapi mahasiswa.

Dimensi reciprocity (timbal balik) dalam katagori baik dengan rata-rata 3,41, 
artinya reputasi yang di miliki Sekolah Tinggi Swasta di Priangan Timur perlu dijaga agar tetap baik di mata mahasiswa dan masyarakat.

Dimensi empaty (empati), adalah dimensi yang terbesar sedangkan dimensi bonding (ketergantungan/ikatan), dimensi yang terbesar kedua sedangkan dimensi reciprocity (timbal balik), dimensi trust (kepercayaan) adalah dimensi yang terendah, untuk dimensi yang terbesar perlu ditingkatkan dan dipertahankan, sedangkan untuk dimensi yang terendah perlu diadakannya perbaikan-perbaikan sehingga strategi relasi pemasaran Sekolah Tinggi Swasta di Priangan Timur khusunya bisa lebih baik, sehingga dapat mendukung terhadap peningkatan Sekolah Tinggi Swasta itu sendiri.

\subsection{Nilai Jasa}

Berdasarkan hasil analisis dari setiap item pertanyaan nilai jasa diukur dalam empat dimensi yaitu: nilai produk, nilai pelayanan, nilai karyawan, nilai citra. Adapun nilai- rata-rata variabel nilai jasa $\left(\mathrm{Y}_{1}\right)$ sebesar 3,19 dengan standar deviasi 0,42170, dengan demikian nilai jasa dalam kriteria cukup baik sampai dengan baik. Kondisi nilai jasa dapat terlihat dari:

Dimensi nilai produk dalam katagori cukup baik dengan rata-rata 3,15, dalam hal ini Sekolah Tinggi Swasta di Priangan Timur harus mengupayakan Unit Pelayanan Teknis/Laboratorium yang di tawarkan Perguruan Tinggi secara baik dan cukup mendukung kegiatan-kegiatan kampus.
Dimensi nilai pelayanan dalam katagori cukup baik dengan rata-rata 3,38, hal ini Sekolah Tinggi Swasta di Priangan Timur perlu menyediakan sarana pembelajaran yang lebih maju dan bisa bersaing dengan Perguruan-Perguruan Tinggi yang lainnya sehingga mahasiswa akan merasa nyaman dalam suasana belajar.

Dimensi Nilai karyawan dalam katagori cukup baik dengan rata-rata 3,00 dalam hal ini Sikap Karyawan /Staf dalam Melayani Mahasiswa pada Perguruan Tinggi harus memiliki nilai-nilai yang baik, dalam melayani mahasiswa sehingga mahasiwa akan memiliki kesan yang positif terhadap kampus.

Dimensi nilai citra dalam katagori cukup baik dengan rata-rata 3,22, hal ini Sekolah Tinggi Swasta di Pringan Timur harus lebih mengutamakan kualitas lulusan sehingga dapat terserap dan bersaing di dunia pekerjaan.

Dimensi nilai pelayanan dan dimensi nilai citra merupakan dimensi yang terbesar sedangkan nilai produk dan Nilai karyawan dimensi yang terendah, dimensi yang terbesar harus terus ditingkatkan dan dipertahankan agar nilai jasa dari Sekolah Tinggi Swasta Priangan Timur bisa lebih baik dan begitu pula untuk dimensi terendah terus diupayakan sehingga bisa meningkat, semua dimensi ini perlu saling mendukung sehingga Sekolah Tinggi Swasta di Priangan Timur memiliki nilai jasa yang lebih kredibel dan berkualitas. 


\subsection{Variabel kepercayaan mahasiswa}

Variabel kepercayaan mahasiswa yang dibentuk oleh 3 (tiga) dimensi dengan 14 indikator menyatakan bahwa dimensi kejujuran (z.1) yang diukur oleh 4 indikator memiliki nilai loading factor sebesar 0,90 dengan nilai $\mathrm{R}^{2}$ sebesar 0,82 , Sedangkan dimensi kredibilitas (z.2) yang diukur oleh 4 indikator memiliki nilai loading factor sebesar 0,96 dengan nilai $\mathrm{R}^{2}$ sebesar 0,91. Dimensi tindakan baik $\left(\mathbf{z}_{.3}\right)$ yang diukur oleh 6 indikator memiliki nilai loading factor sebesar 0,82 dengan nilai $\mathrm{R}^{2}$ sebesar 0,63 .

Berdasarkan hasil tersebut dapat dilihat bahwa Kepercayaan Mahasiswa yang dibentuk oleh 3 (tiga) dimensi sebagai dimensi pembentuk menunjukkan hasil dimensi tertinggi pada tindakan baik, dan dimensi tertinggi kedua pada dimensi kredibilitas. Berdasarkan hasil data yang diperoleh bahwa mayoritas mahasiswa memiliki tindakan baik kepada Sekolah Tinggi Swasta yang dipilihnya, artinya mahasiswa jika mendapat kualitas pendidikan dan layanan yang baik, maka secara tidak langsung mahasiswa akan menunjukkan tindakan baik terhadap kampusnya.

Dimensi kejujuran menjadi dimensi terkecil, walaupun sebagai dimensi terkecil tetapi dimensi kejujuran menjadi faktor penting dalam membentuk kepercayaan bagi mahasiswa, satu sama lain dari dimensi kepercayaan mahasiswa perlu dijalankan dengan baik dan sinergis satu sama lain, sehingga tujuan dari lembaga dapat tercapai.

\subsection{Pengaruh Penerapan Strategi Bauran Pemasaran Terhadap Nilai Jasa}

Berdasarkan hasil pengujian hipotesis menunjukkan penerapan strategi bauran pemasaran jasa mempunyai pengaruh signifikan terhadap nilai jasa, berarti semakin tinggi variasi/ pilihan Program Studi yang ditawarkan Perguruan Tinggi dan Kualitas Program Studi yang ditawarkan dan dengan mengutamakan kualitas pendidikan dan pembelajaran, maka kepercayaan masyarakat akan meningkat, strategi bauran pemasaran ini merupakan hal terpenting bagi Sekolah Tinggi Swasta di Priangan Timur. Berdasarkan hasil penelitian Sekolah Tinggi Swasta di Priangan Timur belum dapat menawarkan Program Studi yang dapat memenuhi harapan Masyarakat, dalam artian masih kalah bersaing dengan Sekolah Tinggi Swasta lainnya yang berada di luar wilayah Priangan Timur.

Strategi bauran pemasaran perlu ditingkatkan agar nilai jasa dari Sekolah Tinggi Swasta di Priangan Timur tersebut bisa meningkat. Hal ini sesuai dengan pendapat Kotler (2000:428), yaitu Produk jasa merupakan "segala sesuatu yang dapat ditawarkan produsen untuk diperhatikan, diminta, dicari, dibeli, digunakan atau dikonsumsi pasar sebagai pemenuhan kebutuhan atau keinginan pasar yang bersangkutan". Produk yang ditawarkan meliputi barang fisik, jasa, orang atau pribadi, tempat, organisasi, dan ide. Jadi produk dapat berupa manfaat tangible maupun intangible yang dapat memuaskan pelanggan. Produk jasa merupakan suatu 
kinerja penampilan yang tidak berwujud dan cepat hilang, lebih dapat dirasakan daripada dimiliki, serta pelanggan lebih dapat berpartisipasi aktif dalam proses mengkonsumsi jasa tersebut. Sesungguhnya pelanggan tidak membeli barang atau jasa, tetapi membeli manfaat dan nilai dari sesuatu yang ditawarkan

Selain itu Place (tempat) merupakan bagian dari bauran pemasaran yang berpengaruh terhada nilai jasa, menurut Zeithalm dan Bitner (2000:436), Lokasi pelayanan jasa yang digunakan dalam memasok jasa kepada pelanggan yang dituju merupakan keputusan kunci. Keputusan mengenai lokasi pelayanan yang akan digunakan melibatkan pertimbangan bagaimana penyerahan jasa kepada pelanggan dan dimana itu akan berlangsung. Tempat juga penting sebagai lingkungan dimana dan bagaimana jasa akan diserahkan, sebagai bagian dari nilai dan manfaat dari jasa.

\subsection{Pengaruh Penerapan Strategi Pemasaran Relasional Terhadap Nilai Jasa.}

Berdasarkan hasil pengujian hipotesis menunjukkan Penerapan strategi pemasaran relasional mempunyai pengaruh signifikan terhadap nilai jasa, berarti semakin tinggi pemasaran relasional yang dilaksanakan Sekolah Tinggi Swasta di Priangan Timur, maka nilai jasa akan meningkat, sehingga perlu meningkatkan pelayanan yang dilakukan Perguruan Tinggi yang sesuai dengan ditawarkan dan karyawan/staf harus ramah dalam melayani mahasiswa. Sekolah
Tinggi Swasta di Priangan Timur perlu memperhatikan dan peduli terhadap permasalahan yang dihadapi mahasiswa dan menjaga reputasi yang di miliki Perguruan Tinggi. Selain itu Sekolah Tinggi Swasta di Priangan Timur perlu mengembangkan dan memelihara hubungan yang baik dan efektif dengan mahasiswa, sehingga pihak Sekolah Tinggi Swasta akan memperoleh nilai yang positif di mahasiswa atau masyarakat. Sesuai dengan pendapat Tandjung (2004:89) menyatakan pemasaran relasional (relationship marketing) adalah pertumbuhan, pengembangan, dan pemeliharaan dalam jangka panjang yang menimbulkan hubungan biaya efektif dengan pelanggan, pemasok, karyawan dan partner-partner lain yang saling menguntungkan. Relationship marketing merupakan suatu praktik membangun hubungan jangka panjang yang memuaskan dengan pihak-pihak kunci meliputi pelanggan, pemasok, dan penyalur guna mempertahankan preferensi bisnis dalam jangka panjang.

\subsection{Pengaruh Penerapan Strategi Bauran Pemasaran Jasa dan Srategi Pemasaran Relasional secara simultan terhadap Nilai Jasa}

Berdasarkan hasil pengujian hipotesis menunjukkan strategi bauran pemasaran jasa dan strategi pemasaran relasional mempunyai pengaruh signifikan terhadap nilai jasa, berarti semakin tinggi variasi/ pilihan Program Studi yang ditawarkan Perguruan Tinggi dan Kualitas Program Studi yang ditawarkan Perguruan 
Tinggi lebih berkualitas maka nilai jasa Sekolah Tinggi Swasta akan tinggi pula. Hal ini disebabkan Program Studi yang ditawarkan secara kualitas belum optimal, dalam artian harus bisa bersaing dengan Sekolah Tinggi Swasta lainnya yang sudah punya kredibilitas yang baik.

Strategi bauran pemasaran jasa dan strategi pemasaran relasional apabila dijalankan dengan baik maka akan berpengaruh terhadap nila jasa Perguruan Tinggi, hal ini sesuai dengan pendapat Berry dan Parasuraman,(2001). Pemasaran jasa efektif tergantung pada pengelolaan kepercayaan pelanggan karena pelanggan biasanya membeli jasa sebelum mencoba jasa tersebut Hasil penelitian Sirdeshmukh et.al., (2002) menunjukan bahwa kepercayaan konsumen mempunyai pengaruh terhadap nilai yang dirasakan oleh konsumen.

Kotler dan Amstrong dalam Tjiptono (2008;160) Apabila Pelanggan merasa puas terhadap Bauran Pemasaran Jasa, maka pelanggan akan melakukan pemakaian jasa ulang, bahkan lebih jauh lagi, mereka akan melakukan promosi dari mulut ke mulut kepada rekan, saudara atau kenalan terdekatnya agar sama sama menggunakan pelayanan jasa untuk berbagai keperluan.

Sedangkan menurut Parasuraman, Berry dan Zeithmal (2001:335), Pengembangan keterkaitan pelanggan merupakan aktivitas relationship marketing yang memfasilitasi pelanggan untuk dapat meningkatkan keterkaitan antara pelanggan dengan perusahaan, perusahaan dengan pemasok, sehingga menimbulkan pertukaran nilai bagi perusahaan. Perusahaan hendaknya dapat menarik pelanggan-pelanggan baru, baik pelanggan potensial maupun pelanggan dari perusahaan pesaing. Itulah sebabnya, perusahaan harus mempertinggi kepuasan pelanggan, agar pelanggan merasa diperhatikan, sangat dibutuhkan, yang pada akhirnya akan bersedia dengan senang hati mempromosikan usaha perusahaan kepada rekan-rekan pelanggan yang lain.

\subsection{Pengaruh Nilai Jasa Terhadap Kepercayaan Mahasiswa}

Berdasarkan hasil pengujian hipotesis menunjukkan nilai jasa memiliki pengaruh terhadap kepercayaan mahasiswa, artinya setiap Perguruan Tinggi perlu mengutamakan nilai atau daya tarik dari setiap layanan yang ditawarkan seperti program studi, predikat akreditasi, kualitas pembelajaran, pelayanan yang baik akademik maupun non akademik yang perlu diberikan oleh Perguruan Tinggi. Lulusan dari Sekolah Tinggi Swasta di Priangan Timur harus dapat bersaing dalam dunia layanan Pendidikan Tinggi, menciptakan lulusan yang unggul dan kompeten, ini semua menjadi nilai jual bagi Perguruan Tinggi. Nila jasa Perguruan Tinggi meningkat, maka kepercayaan mahasiswa akan meningkat pula, sesuai dengan pendapat Kotler dan Keller (2006:25) mengungkapkan pula bahwa: "Suatu perusahaan berhasil menawarkan produk/jasa kepada pelanggan apabila mampu memberikan nilai dan kepuasan (value and satisfaction). 
Secara garis besar, nilai pelanggan adalah perbandingan antara benefit (manfaat) yang dirasakan terhadap suatu produk dengan biaya yang harus dikeluarkan untuk mendapatkan produk tersebut. Untuk mendapatkan nilai pelanggan yang sesuai dengan persepsi pelanggan, maka suatu perusahaan harus selalu mengikutinya dengan menyediakan produk/jasa yang sesuai, karena nilai pelanggan selalu berubah sepanjang waktu.

\section{Sedangkan Barnes (2001:104)} mengungkapkan bahwa, "Nilai bersifat pribadi dan unik." Nilai dikatakan bersifat pribadi dan unik karena nilai terkait dengan manfaat yang mereka terima dari sebuah produk dan biaya yang harus dikeluarkan untuk dapat merasakan manfaat tersebut. Diperkuat pendapat Harjati dalam Usmara (2003:116) Nilai pelanggan menguraikan hubungan antara produk dan pelanggan yaitu pemahaman pelanggan mengenai apa yang mereka inginkan dengan produk/jasa yang ditawarkan dalam memenuhi kebutuhannya dibandingkan dengan biaya yang dikeluarkannya.

\section{Kesimpulan}

Strategi Bauran Pemasaran Jasa berada pada kategori "Cukup Baik", artinya penerapan Strategi Bauran Pemasaran Jasa pada Sekolah Tinggi Swasta di Priangan Timur sudah berjalan dengan cukup baik. Sekolah Tinggi Swasta di Priangan Timur memiliki Program Studi dan Predikat Akreditasi yang ditawarkan cukup berkualitas. Namun demikian masih terdapat beberapa aspek kelemahan diantaranya kemampuan dan sikap tenaga kependidikan/staf masih rendah dalam melayani mahasiswa.

Strategi Pemasaran Relasional berada pada kategori "Baik", artinya strategi pemasaran relasional pada Sekolah Tinggi Swasta di Priangan Timur sudah berjalan dengan baik. Sekolah Tinggi Swasta di Priangan Timur sudah menunjukan reputasi yang baik dimata mahasiswa dan masyarakat. Hal ini terlihat dari kepedulian lembaga terhadap permasalahan yang dihadapi mahasiswa dan kesigapan lembaga dalam menangani permasalahan dengan memberikan solusi yang baik. Namun demikian masih terdapat beberapa aspek kelemahan diantaranya Pelayanan yang dilakukan Perguruan Tinggi belum sesuai dengan yang ditawarkan dan keramahan tenaga kependidikan/staf dalam melayani mahasiswa belum sebagaimana mestinya.

Nilai Jasa Sekolah Tinggi Swasta di Priangan Timur berada pada kategori "Cukup", artinya nilai jasa Sekolah Tinggi Swasta di Priangan Timur sudah terbentuk dengan cukup baik. Hal ini ditunjukan dengan sarana pembelajaran yang dikembangkan pada Perguruan Tinggi sudah relatif lengkap, dan pelayanan nonakademik yang diberikan oleh Perguan Tinggi sudah dirasakan dengan baik oleh mahasiswa. Namun demikian masih terdapat beberapa aspek kelemahan diantaranya; daya tarik/variasi Program Studi yang di tawarkan serta penampilan tenaga kependidikan yang masih belum tertata dengan baik.

Kepercayaan Mahasiswa berada pada kategori "Cukup Baik", artinya kepercayaan mahasiswa terhadap Sekolah 
Tinggi Swasta di Priangan Timur sudah baik. Hal ini ditunjukan dengan lulusan Perguruan Tinggi mudah terserap oleh lapangan pekerjaan.

Strategi bauran pemasaran jasa berpengaruh positif dan signifikan terhadap nilai jasa, artinya semakin meningkat strategi bauran pemasaran jasa maka nilai jasa akan meningkat. Strategi bauran pemasaran jasa dominan dibentuk dimensi produk (product) dan harga (price), dan dimensi terkecil dimensi sarana (Phisical Evidance) dan SDM (people) namun berjalannya startegi bauran pemasaran jasa dibentuk oleh semua dimensi, baik dimensi terbesar maupun terkecil semua saling mendukung satu sama lain.

Strategi pemasaran relasional berpengaruh positif dan signifikan terhadap nilai jasa, artinya semakin meningkat strategi pemasaran relasional maka akan meningkatkan nilai jasa pada Sekolah Tinggi Swasta di Priangan Timur. Strategi pemasaran relasional lebih dominan dibentuk dimensi empati dan dimensi tertinggi kedua pada dimensi ketergantungan. Berdasarkan dari hasil data yang diperoleh Kepercayaan mahasiswa terhadap kejujuran, keseriusan, dan komitmen perguruan tinggi dalam melayani dan meningkatkan kualitas layanannya sudah baik dirasakan mahasiswa, disamping itu kepedulian dan keramahan berbagai pihak yang merupakan bagian unsur Perguruan Tinggi didalamnya terdiri dari dosen dan tenaga kependidikan yang sudah dirasakan baik oleh mahasiswa.

Strategi bauran pemasaran jasa dan strategi pemasaran relasional secara simultan memiliki pengaruh positif dan signifikan terhadap nilai jasa, artinya semakain tepat strategi bauran pemasaran jasa melalui variasi/pilihan program studi dan strategi pemasaran relasioanal dalam bentuk kepedulian lembaga terhadap masalah yang dihadapi mahasiswa maka akan membentuk Nilai Jasa Perguruan Tinggi Swasta lebih Tinggi.

Nilai jasa memiliki pengaruh positif dan signifikan terhadap kepercayaan mahasiswa, artinya bahwa dengan komitmen lembaga senantiasa mengembangkan sarana pembelajaran dan pelayanan non-akademik yang baik yang diberikan pada mahasiswa akan menciptakan kepercayaan mahasiswa terhadap lembaganya.

\section{Referensi}

A.Usmara dan Budiningsih. B., 2003. Marketing Classics, Penerbit Amara Books, Jogjakarta.Ahmad Ikhwan Setiawan. 2002. Analisis Perilaku Konsumen dan Lingkungan

Bejou, D., Ennew, C.T., and Palmer, A., 1998. "Trust, Ethics and Relationship Satisfaction. International Journal of Bank Marketing, 16 (4), 170-175. 
Buchari Alma. 2005. Manajemen Pemasaran dan Pemasaran Jasa, Edisi keenam, Alfabeta, Bandung.

Fandy Tjiptono. 2005. Pemasaran Jasa. Bayumedia, Malang.

Fandy Tjiptono, Gregorius Chandra, dan Dadi Adriana. 2008. Pemasaran Strategik, Penerbit Andi, Yogyakarta.

Fornell, Claes. 1992. "A National Customer Satisfaction Barometer: The Swedish Experience". Journal Of Marketing, Vol. 56.

Freddy Rangkuti. 2003. Measuring Customer Satisfaction, cetakan kedua, Penerbit Gramedia Pustaka Utama, Jakarta.

Gareth R. Jones and Mary Mathew. 2009. Organizational Theory, Design and Change, 5th Edition (Delhi : Dorling Kindersley,) p.1 478

Gibson, J.L.,Ivancevich, J.M.,\&Donnelly, J.H.2000. Organizations:Behavior, Structure,Processes. 10th ed. Boston: McGraw-Hill.

Giese, J.L and J.A. Cote. 2000. Defining Customer Satisfaction, Academy of Marketing Science Review, Vol. 2000, No. 1.

Griffin, R.W. and Moorhead, G. 1996. Organizational Behavior. Boston:Houghton Miffin Company.

Gronroos, Christian. 1982. "Strategic Management and Marketing in The Services Sector", Helsingfor: Swedish School of Economic and Business Administrations.

Hawkins, Best, Coney. 2004. Consumer Behavior: Building Marketing Strategy, Mc GrawHill, USA.

Healy, Genevieve. 2008. Strategic Marketing Analysis, $2^{\text {nd }}$ edition, Thomson, Australia.

Hermawan Kartajaya. 1996. 36 Kasus Pemasaran Asli Indonesia, PT. Elex Media Komputindo, Jakarta.

Kinnear, Thomas C and James R. Taylor. 1996. "Marketing Research: An Applied Approach,fifth edition,USA.

Koontz, Christine M. 2001. Glossary of Management and Marketing, Florida States University.

Koontz, Harold, Cyril O'Donnel, and Weihrich. 1980. Management, $7^{\text {th }}$ Edition, McGrawHill, Kogakusha Ltd.

Koontz, Harold and Heinz Weihrich, 2007. Essentials of Management: An International Perspectives, 7th Edition (New Delhi: Tata McGraw-Hill,) p.5. 
Kotler, Philip and Amstrong G. 2001. Principle of Marketing, eleventh edition, New York: Prentice Hall.

Kotler, Philip and Kevin Lane Keller. 2007. Manajemen Pemasaran, alih bahasa Benyamin Molan, Penerbit Erlangga, Jakarta.

_ 2009. Manajemen Pemasaran, alih bahasa Bob Sabran, Penerbit PT. Indeks,Jakarta.

_ 2012. MarketingManagement, fourteenth edition, Pearson Prentice Hall.

Kotler, Philip., Bowen, John T., and Makens, James C. 2010. Marketing for Hospitality and Tourism, fifth edition, Perason Prentice Hall, United States.

Lamb CWJr, Hair JFJr, Mc Daniel C. 1999. Essential of Marketing, Ohio: South western Publishing.

Lovelock, Christopher and Lauren Wright. 2005. Manajemen Pemasaran Jasa, alih bahasa Agus Widyantoro, PT. Indeks, Jakarta.

Lovelock, Christopher, H., and Lauren K Wright. 2007. Manajemen Pemasaran Jasa, edisi Bahasa Indonesia, alihbahasa oleh Ir. Agus Widyantoro, PT. Indeks, Jakarta

Lovelock,C. and J. Wirtz. 2004. Service Marketing: People, Technology, Strategy, fifth edition, Pearson-Prentice Hall, Canada.

Mullins, John W, and Walker, Orville C, JR. 2010. Marketing Management, a Strategic Decision-Making Approach, Seventh Edition, McGraw-Hill International, New York, America.

Oliver, R. L. 1997. Satisfaction: A Behavioral Perspective on the Consumer, New York: Mc GrawHill. Peppers D and Rogers, M. 2004. Managing Customer Relationships. Hoboken, New Jersey: John Wiley \& Sons. Inc.

Peter, Paul J. and Oslo, Jerry. 1996. Consumer Behavior, 6 ed, pg. 6. Peter-Olson. 2002. Consumer Behavior and Marketing Strategy, Eighth Edition, McGraw-Hill

Rambat Lupiyoadi dan A. Hamdani. 2006. Manajemen Pemasaran Jasa, Penerbit Salemba Empat, Jakarta.

Ratih Hurriyati. 2008. Bauran Pemasaran dan Loyalitas Konsumen, Alfabeta. Ratnasingam, P. and DD Phan. 2003. "Perdagangan Rekanan Trust di B2B E-Commerce: StudiKasus. Sistem Informasi Manajemen, vol. 20, no 3, hal.39-50.

Ravald, A and Gronroos, C. 1996. "The Value Concept and Relationship Marketing". European Journal Of Marketing 30 (2): 19-30. 
Rhenald Kasali. 1998. Membidik pasar Indonesia: Segmentasi, Targeting dan Positioning, cetakan kedua, PT. Gramedia Pustaka Utama, Jakarta.

Ristiyanti Prasetijo dan John J.O.I Ihalauw. 2005. Perilaku Konsumen, Andi, Yogyakarta.

Robbins, Stephen P. and May Coulter. 2012. Management. Eleventh edition. Pearson Education Limited.

Slater. 1997. "Developing a Customer Value-Based Theory of The Firm". Journal of the Academy of Marketing Service, Vol. 25 pp. 162-167.

Solomon, Michael R., Greg W. Marshall, Stuart, and Elnora W. 2009.Marketing, Real People, Real Choices, sixth edition, Pearson International Edition, New Jersey.

Stephen Robbins. 1994. Teori Organisasi, Struktur, Desain dan Aplikasi, alihbahasa Jusuf Udaya, Penerbit Arcan.

Sucherly. 2002. Strategi Pemasaran Jasa Dalam Meningkatkan Keunggulan Bersaing, Jurnal Bisnis dan Manajemen, Fakultas Ekonomi Universitas Padjadjaran Bandung, Vol. 1. No. 1, 2002, hlm 61-80.

Sugiono. 2004. Metode Penelitian Bisnis. Cetakan ketujuh. Alfabeta, Bandung. Sung-kwon Hong, Sang-Woo Lee, Seokho Lee, and Hochan Jang. 2009.

Tam JLM. 2000. "The effects of service quality, perceived value and customer satisfaction on behavioral intentions". J. HHosp. Leis. Mark., 6(4): 31-43.

Terry, G.R. 1978. Principle of Management, 7thEd. Homewood Illinois, Richard D. Irwin Inc. 496

Tse, D. K., and Wilton, P. C. 1988. "Models of Consumer Satisfaction Formation: An Extension”. Journal of Marketing Research, 25 (2), 204 -212.

Ujang Sumarwan, dkk. 2010. Pemasaran Strategik: Perspektif Value Based Marketing dan Pengukuran Kinerja, Penerbit IPB Press, Bogor.

Wen-Hwa Ko and Chihwei P. Chiu. 2008. "The Relationships Between Brand Attitude, Customers' Satisfaction and Revisiting Intentions of the University Students-A Case Study of Coffee Chain Stores in Taiwan". Journal of Foodservice Business Research Volume 11, Issue 1, 2008.

Yi, Y. 1991. A Critical Review of Consumer Satisfaction. In Review of Marketing, V. A. Zeithaml, ed., 68-123. Chicago: American Marketing Association. Zeithaml, V. A., L. L. Berry, and A. Parasuraman. 
Zboja, James J. and Clay M. Voorhees. 2006. "The Impact of Brand Trust and Satisfaction". Journal of Services Marketing, Volume 20., Number.5 p.381 - 390.

Zikmund, William G, 2003. Customer Relationship Management: Integrating Marketing Strategy and Information Technology. USA: John Willey \& Sons, Ltd.

\section{Peraturan}

Undang-Undang No.20 Tahun 2003 tentang Sistim Pendidikan Nasional

Undang- Undang No.12 Tahun 2012 tentang Pendidikan Tinggi

Keputusan Menteri Pendidikan Nasional RI No.232/U/2000 tentang Pedoman Penyusunan Kurukulum Pendidikan Tinggi dan Penilaian Hasil Belajar Mahasiswa

Keputusan Menteri Pendidikan Nasional RI No. 232/U/2002 Tentang Kurikulum Inti Perguruan Tinggi

Peraturan Presiden Republik Indonesia Nomor 8 Tahun 2012 Tentang Kerangka Kualifikasl $\underline{\text { Nasional lndonesia }}$

Peraturan Menteri Pendidikan Nasional Nomor 63 Tahun 2009 Tentang Sistem Penjaminan Mutu Pendidikan

Peraturan Menteri Pendidikan Nasional Nomor 67 Tahun 2009 Tentang Akreditasi Berkala IImiah

Peraturan Menteri Pendidikan Nasional Nomor 17 Tahun 2010 Tentang Pencegahan dan Penanggulangan Plagiat di Perguruan Tinggi 